\title{
Integrated Performance Management Using Information Technology, a Study of UK Charities
}

\begin{abstract}
This paper explores how UK charities use Information Technology (IT) to support Integrated Performance Management (IPM). Based on six case studies of small-medium-sized charities (SMCs), it finds that SMCs see IT as important for IPM, but face significant barriers establishing effective IPM due to the multi-dimensional nature of their operations and stakeholders and their lack of IT infrastructure. The paper concludes that charities would benefit from a more strategic infrastructure approach to IT, integrating IT for data, information and knowledge.
\end{abstract}

Keywords: Charities; Integrated Performance Management; Information Technology; Case Study

\section{Introduction and background}

Charities need to provide relevant and timely accounts of their activities and impact to a wide range of external stakeholders, e.g. funders, donors, regulators and beneficiaries, each with specific requirements. In addition to - and as a foundation for - external reporting, charities need to understand and internally report on their performance. Both can be complicated due to charities often operating - internationally, nationally and locally - through dispersed networks and partnerships. As a sub-set of third sector organisations (TSOs), charities face the same performance management (PM) problems as the wider sector. Anheier (2000) argues that TSOs are more complicated to account for than corporations because they are multi-dimensional (social and financial) and have multiple stakeholders. Nicholls (2010) notes that accounting for different purposes requires a blended values approach using a variety of measurement and reporting methods. Charities use narrative to explain the public benefit of their objectives (Morgan, 2013) and a wide variety of methods to measure and report on their impact. Organisations such as New Philanthropy Capital are developing performance indicators and benchmarks for the sector (Connolly \& Hyndman 2013).

Moxham (2014), through a systematic review of current literature, finds that TSOs are driven to measure performance for reasons of accountability (to multiple stakeholders), legitimacy and efficiency (allocation of resources and effectiveness of activities). Moxham's review found that the most prevalent methods of measurement are reputational (based on surveys of staff, beneficiaries, partners) and multi-dimensional (employing several different methods for measuring). The rational 
goal attainment model - widely used in the private sector - arguably does not translate well to the third sector. Themes emerging are the lack of resources for data collection and analysis; success being more likely with performance monitoring built into day to day activities; the problem of attribution when evaluating collaborative action and the danger of spending resources on measurement rather than on programme delivery (see also Dacombe, 2011 and Luke et al., 2013). Cordery and Sinclair (2013, p.206) ask "how do (or can) TSOs strengthen their reporting so that it informs strategy and ensures the organisation stays close to its values, rather than being merely "what the funder/donor wants"?"

Against this background, the premise of our study is two-fold: firstly, charities' reporting challenges are best addressed using an integrated approach to performance management, and, secondly, they need Information Technology (IT) to support this. We suggest that IT can play a key role in helping charities address the dual challenge of reporting to internal and external stakeholders with varying demands, with the reports necessarily based on data and information from a wide range of sources and in different formats.

Whereas some charities make good use of IT and there is some evidence of IT positively impacting on charity performance (Kobelsky et al. 2014), its strategic application is generally under-exploited (Hackler and Saxton, 2007; Zorn et al., 2011). There are also many barriers and constraints for effective use of IT in charities (Clerkin and Grønbjerg, 2007; Cortés and Rafter, 2007; Wolpert and Seley, 2007; Manzo and Pitkin, 2007). The aim of this paper therefore is to explore how small and medium-sized charities (SMCs) use IT to support integrated PM, including any barriers and drivers they experience.

\section{Integrated performance management}

Most organisations find it hard to produce performance management information because underlying data is often spread over multiple systems for different functions, locations and units (Neely et al., 2008). This problem is exacerbated in charities. They often work in networks and on collaborative projects, and external information may be needed to report on impact. Literature suggests that so-called 'Enterprise Performance Management' (EPM), (or 'Corporate Performance Management', 'Business Performance Management' or 'Strategic Performance Management') could address such issues. These terms broadly refer to the strategic management of performance at a corporate or enterprise level (e.g. Marr, 2008; Dresner, 2008). However, the terms 'Corporate', 'Enterprise' and 'Business' do not resonate well in a charity context, while 'Strategic' underplays some of the reporting elements. This paper therefore will explore the term 'Integrated Performance 
Management' (IPM), focussing on the integration of internal and external reporting, and the underpinning integrated collection and use of data and information through a range of sources. This terminology is in line with Moxham (2014) as discussed above.

In the literature, IT support is often explicitly identified as a key enabler for IPM (e.g. Frolick and Ariyachandra, 2006). IT for IPM combines two main functions: drawing data from disparate sources (including external ones), and using analytical and visualisation tools for analysing the data, presenting outcomes in user-friendly formats and providing scenarios. As Melchert and Winter (2004) suggest, IPM can function with the co-ordinated design and use of existing hardware and software, rather than necessarily requiring separate, new software tools. In order to analyse the IPM needs for charities, the 'DIKAR' (Data, Information, Knowledge, Action, Results) model (Ward and Peppard, 2016) is used. A pragmatic model, DIKAR shows how data - via information, knowledge, and action - ultimately relates to organisational results (see Figure 1).

Figure 1. DIKAR model (Ward and Peppard (2016), p.146)

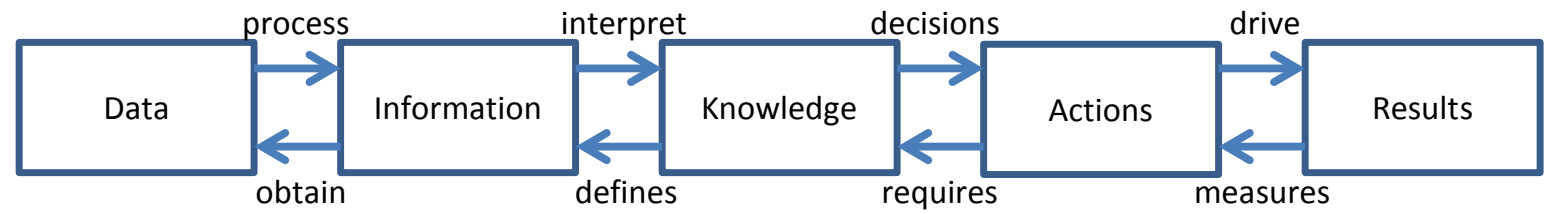

Our approach is broader than Moxham's (2013) conceptual framework for performance measurement, which focuses on data, information and learning. By including organisational action and results, rather than learning, the DIKAR model allows for a more explicit link between data and information and the management of performance. Table 1 outlines definitions of the elements of the DIKAR model.

\begin{tabular}{|l|l|}
\hline & Definition \\
\hline Data & Facts about the world (Checkland and Holwell, 1998) \\
\hline Information & Data with attributed meaning in context (Checkland and Holwell, 1998) \\
\hline Knowledge & Information combined with experience, interpretation and reflection (Davenport et al.,1998) \\
\hline Actions & $\begin{array}{l}\text { Organisational actions, resulting from the use of information and application of knowledge - range from } \\
\text { single decisions to complex programmes (Ward and Peppard, 2016) }\end{array}$ \\
\hline Results & Organisational results, outcomes and impacts (Ward and Peppard, 2016) \\
\hline Table 1. & \multicolumn{1}{c|}{ Definitions of DIKAR model elements }
\end{tabular}

\section{Charity use of IT}

There is limited academic literature specifically on charity use of IT. In their analysis of practical relevance of articles published between 2000 and 2015 in Nonprofit and Voluntary Sector Quarterly, 
Bushouse and Sowa (2012) identify only 2 articles out of 408 focussing on IT. While there is some interest in particular areas of IT application in charities, such as social media (e.g. Svenson et al., 2015; Emrich and Pierdzioch, 2016) and online disclosure (e.g. Saxton and Guo, 2011), there is little research on charities' ability to use IT in general, or for PM in particular.

In this paper, we focus on identifying drivers and barriers for SMCs to effectively use IT to support IPM. As with for-profit organisations, size of organisation is the strongest predictor for IT capacity (Clerkin and Grønbjerg, 2007). Other major factors that inhibit charity IT use are also largely related to size, such as funding and budget, time, staffing, training, and access to expertise (Cortés and Rafter, 2007; Wolpert and Seley, 2007; Manzo and Pitkin, 2007). While it is useful to refer to literature on IT use in small-medium sized enterprises (e.g. Caldeira and Ward, 2003) to understand the issues related to size, charities have additional specific characteristics and challenges, in particular related to funding and being mission-driven (Zhang et al., 2010). Zhang et al. (2010) suggest that charities view IT differently from for-profits, including regarding IT as a burden, suggesting that management and user attitudes towards IT are potential issues. This paper will mainly focus on charity-specific barriers and drivers.

Further charity-specific factors mentioned in literature include hard to measure goals, and external pressures (e.g. to invest in particular technologies) (Cortés and Rafter, 2007). Many charities also face pressure to reduce their overhead costs, including IT spending, in order for money to be spent directly on achieving charitable aims (Sloan, 2013). Furthermore, decisions on IT can be hampered by the diversity of stakeholders involved (Zhang et al., 2010). However, there is evidence that charities explore the application of innovative IT, particularly where directly related to fulfilling their charitable purpose (e.g. Gallegos et al., 2011).

\section{Case studies}

The aim of the empirical part of this study is to explore how SMCs use IT to support IPM. As research in this area is not well-developed, an exploratory case study strategy was adopted (Benbasat et al., 1984). This research strategy allows investigating the complex and contextual nature of IPM, asking 'how' and 'why' questions (Yin, 2014). Our approach is interpretivist (Walsham, 1995), primarily using semi-structured interviews to gather evidence of practices and experiences.

The case organisations were approached after discussions with UK charity umbrella bodies and a request through Linkedln for interested charities to participate. The organisations all have some 
elements of IPM and reflect a range of characteristics typical of the field (see Table 2). The final row in Table 2 provides an overview of the 28 interviewees and their management or trustee roles.

\begin{tabular}{|c|c|c|c|c|c|c|}
\hline Alias & Acorn & Bramble & Oak & Plane & Vine & Willow \\
\hline Sector & $\begin{array}{l}\text { Social action/ } \\
\text { youth }\end{array}$ & $\begin{array}{l}\text { Arts/ } \\
\text { youth }\end{array}$ & Welfare & $\begin{array}{l}\text { Arts/ } \\
\text { theatre }\end{array}$ & $\begin{array}{l}\text { Children/ } \\
\text { development }\end{array}$ & $\begin{array}{l}\text { Disabled/ } \\
\text { development }\end{array}$ \\
\hline Scope & National & International & National & Regional & International & International \\
\hline Structure & $\begin{array}{l}\text { Central head } \\
\text { office with } \\
\text { regional offices }\end{array}$ & $\begin{array}{l}\text { Works with third } \\
\text { party organisations } \\
\text { and schools }\end{array}$ & $\begin{array}{l}\text { Central head } \\
\text { office serving } \\
\text { UK }\end{array}$ & $\begin{array}{l}\text { UK market } \\
\text { town office }\end{array}$ & $\begin{array}{l}\text { UK office working } \\
\text { internationally with } \\
\text { nearly } 3,000 \\
\text { organisations through } \\
\text { local networks }\end{array}$ & $\begin{array}{l}\text { UK head office, } \\
\text { international } \\
\text { offices }\end{array}$ \\
\hline $\begin{array}{l}\text { Organisation } \\
\text { age }\end{array}$ & $<10$ years & $20-30$ years & $>100$ years & $\begin{array}{l}\text { Origin }>100 \\
\text { years, current } \\
10-20 \text { years. }\end{array}$ & $10-20$ years & $20-30$ years \\
\hline Income/year & $<f 500 K$ & $<f 500 K$ & f1-2M & f2-5M & $f 2-5 M$ & f2-5M \\
\hline Trading & Yes & Yes & No & Yes & No & Yes \\
\hline $\begin{array}{l}\text { Elements of } \\
\text { IPM }\end{array}$ & $\begin{array}{l}\text { IT investment, } \\
\text { enhanced data } \\
\text { collection, } \\
\text { process } \\
\text { optimisation }\end{array}$ & $\begin{array}{l}\text { PM informing } \\
\text { strategy, innovative } \\
\text { data collection on } \\
\text { impact }\end{array}$ & $\begin{array}{l}\text { Planned IT } \\
\text { investment to } \\
\text { support PM } \\
\text { for new } \\
\text { strategy }\end{array}$ & $\begin{array}{l}\text { Use a simple } \\
\text { integrated } \\
\text { system for } \\
\text { PM }\end{array}$ & $\begin{array}{l}\text { Strategic PM use, in- } \\
\text { house developed } \\
\text { impact measurement } \\
\text { system }\end{array}$ & $\begin{array}{l}\text { Moving to cloud- } \\
\text { based system for } \\
\text { integrated data } \\
\text { collection }\end{array}$ \\
\hline Interviewees & $\begin{array}{l}\text { CEO, Executive } \\
\text { Support, } \\
\text { Networks, } \\
\text { Programmes, } \\
\text { Trustee }\end{array}$ & $\begin{array}{l}\text { CEO, Treasurer, } \\
\text { Trustee, } \\
\text { Finance }\end{array}$ & $\begin{array}{l}\text { CEO, Finance, } \\
\text { External IT } \\
\text { Consultant, } \\
\text { Trustee }\end{array}$ & $\begin{array}{l}\text { CEO, Box } \\
\text { office, } \\
\text { Finance, } \\
\text { Trustee }\end{array}$ & $\begin{array}{l}\text { CEO, Finance and IT, } \\
\text { Operations, Trustee }\end{array}$ & $\begin{array}{l}\text { CEO/founder, } \\
\text { Materials, } \\
\text { Finance Director, } \\
\text { Logistics/Finance, } \\
\text { Project, Supply } \\
\text { chain, Trustee }\end{array}$ \\
\hline
\end{tabular}

Table 2. Characteristics of case organisations - including IPM elements - and interviewees

The interviews took place at the charity premises, except for two telephone interviews. Interviews lasted on average 46 minutes and were digitally recorded and professionally transcribed. Interview topics were based on a literature review and discussions with charity umbrella and professional bodies. Additional documentation such as annual reports was also collected.

\section{IT drivers and barriers}

Table 3 below provides an overview of IT drivers and barriers to IPM in the case organisations. For the table, charity-specific factors from the literature were amended based on case study findings. The charities in this study are keen to exploit the use of IT, but demonstrate a variety of IT capabilities and systems, with some showing innovative IT use in relation to achieving their charitable aims (factor 9 in the table). As expected, as SMCs they face many challenges, but the general attitude is positive and ambitious. In contrast to Zhang's (2010) suggestion that charities see IT as a burden, it was found that IT is generally seen as useful (factor 1), partly driven by a desire/need to provide an evidence-base for impacts (factor 2). While skills levels are variable, there is limited resistance to IT. Willow's CEO's statement is quite typical: "You've got a variety of people like you would in any organisation, there's people that are really keen and enthusiastic about it, and there's people that are terrified of it.".

\begin{tabular}{|l|l|l|l|l|l|l|}
\hline Acorn & Bramble & Oak & Plane & Vine & Willow & Overall \\
\hline
\end{tabular}




\begin{tabular}{|c|c|c|c|c|c|c|c|c|}
\hline 1. & Management and user attitudes towards IT & + & + & $+/-$ & + & + & + & Driver \\
\hline 2. & Desire/need for evidence base for impacts & + & + & + & + & + & + & Driver \\
\hline 3. & Diversity of stakeholders for IT decisions & 0 & 0 & - & 0 & 0 & 0 & Neutral \\
\hline 4. & Lack of expertise and infrastructure & - & 0 & - & 0 & $+/-$ & - & Barrier \\
\hline 5. & $\begin{array}{l}\text { Pressure to minimize overheads and focus on } \\
\text { charitable aims }\end{array}$ & 0 & 0 & 0 & 0 & - & - & Barrier \\
\hline 6. & $\begin{array}{l}\text { Corporates providing software and services at } \\
\text { reduced cost }\end{array}$ & + & 0 & 0 & 0 & 0 & + & Driver \\
\hline 7. & $\begin{array}{l}\text { IT savvy organisations and individuals keen to } \\
\text { help }\end{array}$ & + & 0 & 0 & + & 0 & + & Driver \\
\hline 8. & Support from networks and umbrella bodies & + & + & 0 & + & 0 & + & Driver \\
\hline 9. & Innovative IT use to achieve charitable aims & 0 & + & 0 & + & 0 & + & Driver \\
\hline 10. & Availability of low cost/cloud solutions & + & + & + & 0 & 0 & + & Driver \\
\hline 11. & Operating in networks and/or with partners & 0 & - & 0 & 0 & - & - & Barrier \\
\hline
\end{tabular}

\section{Table 3. IT drivers and barriers for IPM in the case organisations}

The case organisations often lack expertise and infrastructure (factor 4). IT infrastructure refers to the combined hardware, software and network resources, which enable the use of IT in the organisation. 'Lack of infrastructure' as a factor was not mentioned in the literature as such, but it featured across the case organisations. This shows an appreciation of the need for an infrastructural - rather than ad-hoc - approach to IT. Infrastructure and expertise take a prolonged and concerted effort to build up, but can, to some extent, be bought in. All case organisations make some use of external consultants and they are interested in cloud solutions. Some experiences are negative, 'It would be so nice if they did have an IT company that specialized in charities and not try and just snare you in the first place and then rip you off for evermore' (Finance, Willow), but others receive excellent external support, both from regular suppliers and pro bono. Taking the factors relating to external support and discounts together (factors 6-8), the case study organisations demonstrate that there are clear opportunities to develop external infrastructural solutions for SMCs, using cloud technologies (factor 10) and working with partners (factor 11).

\section{Charity IPM in practice}

This section uses the DIKAR model to specifically analyse IPM practice and related IT use. Tables 4-7 show key findings for each DIKAR element, together with quotes for evidence and clarification.

\section{Data}

As table 4 shows, data is important for charities in the context of their PM and their desire to provide reliable information (next section).

\begin{tabular}{|l|l|l|}
\hline \multicolumn{2}{|l|}{ Case study findings } & Key supporting quotes \\
\hline \multirow{2}{|c|}{$\begin{array}{l}\text { Data is recognized in all case } \\
\text { organisations as a valuable resource } \\
\text { essential for reliable and useful } \\
\text { reporting. }\end{array}$} & $\begin{array}{l}\text { "What we'll be able to do is hopefully prove that we're robust [...] we can be } \\
\text { like, 'Well we know that we actually do do this,' categorically. But [...] the } \\
\text { data's got to be good before you can really start having those } \\
\text { conversations." (Acorn, CEO) }\end{array}$ \\
\hline
\end{tabular}




\begin{tabular}{|c|c|c|}
\hline & $\begin{array}{l}\text { A recognized need to broaden data } \\
\text { collection, in particular in relation to } \\
\text { impact measurement. Data may be } \\
\text { hard to collect and impact is often } \\
\text { hard to measure. Standardisation of } \\
\text { impact measures is seen as helpful. }\end{array}$ & $\begin{array}{l}\text { "... because how do you know if you're winning? I know all the children that } \\
\text { we encounter and that we work with and that we actually remove from the } \\
\text { streets, but you don't know ultimately whether more come in from other } \\
\text { places ... so there are mechanisms out there in terms of data that I need but } \\
\text { that's hard to get as an organisation." (Vine, operations). }\end{array}$ \\
\hline & $\begin{array}{l}\text { Limited current use of external data, } \\
\text { unless explicitly part of the operating } \\
\text { model. }\end{array}$ & $\begin{array}{l}\text { "... think that pooling of data could be really powerful." (Plane, box office } \\
\text { and marketing) }\end{array}$ \\
\hline \multirow{3}{*}{$\stackrel{\Xi}{\Xi}$} & $\begin{array}{l}\text { Some imaginative use of technology to } \\
\text { collect rich data and facilitate field } \\
\text { data collection. }\end{array}$ & $\begin{array}{l}\text { "...it's so simple, so you're filling out a form on a touch screen. But also on the } \\
\text { iPad you've got a camera, you've got a video, you've got voice recording." } \\
\text { (Willow, CEO). }\end{array}$ \\
\hline & $\begin{array}{l}\text { The operating model impacts IT use } \\
\text { and data challenges - in particular for } \\
\text { charities using (international) } \\
\text { networks and overseas partners - e.g. } \\
\text { lack of control over format and } \\
\text { timeliness of data, and exponential } \\
\text { scope of data to be collected. }\end{array}$ & $\begin{array}{l}\text { "We have to get information from our overseas branches and a lot of that } \\
\text { is just based on manual cash books or cash books that are done on Excel } \\
\text { [...]." (Willow, finance). } \\
\text { "...we don't have the resources to track individual people across all of our } \\
\text { programmes, [...]. It's been challenging and the challenge of training your } \\
\text { staff in each country to understand the systems and to accurately send the } \\
\text { correct information every month and keep their own records up to date } \\
\text { and send them to us." (Willow, project development) }\end{array}$ \\
\hline & $\begin{array}{l}\text { All case organisations have gone } \\
\text { through - and are planning - IT } \\
\text { changes relating to data collection and } \\
\text { reporting. Key aims are easy access to } \\
\text { data, having data in one location and } \\
\text { reducing manual processing. }\end{array}$ & $\begin{array}{l}\text { "ideally we would like a nice CRM system which is then, it's much easier to } \\
\text { plug in any needs" (Oak, Finance) } \\
\text { "we do have at the moment a completely separate system [...] which is a } \\
\text { web-based completely separate database independent of everything. Now } \\
\text { eventually what we want to do is get that at least onto the platform } \\
\text { SharePoint." (Vine, CEO) }\end{array}$ \\
\hline
\end{tabular}

Table 4. Case study findings for 'Data' element of DIKAR

As expected, complex as well as international operating models provide a challenge, confirming the need for an integrated approach. There are two key types of solutions for such integration: those that facilitate/automate data collection at source, e.g. using a CRM or providing field workers with an iPad and app, and those using shared platforms.

\section{Information}

Table 5 below provides an overview of key findings for 'information'. While generally satisfied with their information provision and ability to meet reporting requirements, the charities experience challenges in fully expressing their complex operations and impacts. This drives a desire to collect better data (previous section), but also highlights the importance of information providers' and receivers' knowledge (next section).

\begin{tabular}{|c|c|c|}
\hline \multicolumn{2}{|c|}{ Key case study findings } & Key supporting quotes \\
\hline & $\begin{array}{l}\text { The charities want decisions to be based on } \\
\text { reliable information and are reasonably happy } \\
\text { with the information they provide. They also } \\
\text { unanimously see scope for improvement. }\end{array}$ & $\begin{array}{l}\text { "...if you don't know where you are it's impossible. So the } \\
\text { information is absolutely key ..." (Vine, trustee) } \\
\text { "We understand where the gaps are and where the analysis is } \\
\text { weak..." (Acorn, CEO) }\end{array}$ \\
\hline 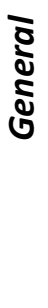 & $\begin{array}{l}\text { Challenges to information provision - in } \\
\text { particular impact reporting - are influenced by } \\
\text { the charity's operating model, e.g. general } \\
\text { complexity and working through networks. }\end{array}$ & $\begin{array}{l}\text { "...in any networking organisation you don't have the privilege of } \\
\text { having a simple offering [...] that shows you without you it's not } \\
\text { working and with you it is working..." (Vine, CEO) } \\
\text { "...it's about making it simpler, it's about irrespective of how } \\
\text { complicated the box of tricks is, you've got to represent it in a very } \\
\text { straightforward way." (Vine, operations) } \\
\text { "...it's like headline news about what's happening but it only } \\
\text { captures a fraction of what's actually happening and we can't }\end{array}$ \\
\hline
\end{tabular}




\begin{tabular}{|c|c|c|}
\hline & & $\begin{array}{l}\text { aggregate it in any really simple way yet." (Willow, project } \\
\text { development). }\end{array}$ \\
\hline & $\begin{array}{l}\text { Reports are important, but not sufficient in } \\
\text { themselves; they primarily form the basis of } \\
\text { discussions and conversations. }\end{array}$ & $\begin{array}{l}\text { "...be able to have meaningful discussion in the meeting" (Acorn, } \\
\text { trustee). } \\
\text { "It's a conversation starter..." (Vine, operations). }\end{array}$ \\
\hline & $\begin{array}{l}\text { Integrated management of reporting to } \\
\text { different stakeholders (based on a wide range } \\
\text { of pooled data) highlights strategic alignment } \\
\text { of internal and external information needs. }\end{array}$ & $\begin{array}{l}\text { '..we should be reporting against these things anyway for the good } \\
\text { functioning of the management team, and trustees are there for a } \\
\text { bit of check and balance' (Acorn, CEO) }\end{array}$ \\
\hline \multirow[t]{2}{*}{$\begin{array}{l}\stackrel{\Xi}{S} \\
\Sigma\end{array}$} & $\begin{array}{l}\text { IT investments aim to improve processes of } \\
\text { generating information, including increasing } \\
\text { automation of data processing and report } \\
\text { generation; challenges here, especially around } \\
\text { integration, are impacted by both age and } \\
\text { scope of the organisations. }\end{array}$ & $\begin{array}{l}\text { "We've really streamlined the process to be far more efficient, and } \\
\text { so they get a lot more data than they used to, in a more useful } \\
\text { format" (Acorn, network) } \\
\text { "...at the end of that input you get an automated report by pushing } \\
\text { a button. It automatically scores and it automatically gives you a } \\
\text { report." (Vine, operations) } \\
\text { "None of the systems talk, and that's nobody's fault, it's just that } \\
\text { each thing has been developed for a different reason" (Willow, } \\
\text { project development) }\end{array}$ \\
\hline & $\begin{array}{l}\text { Analysis and visualisation are largely done } \\
\text { using simple tools (e.g. Excel), but there is } \\
\text { interest in using more sophisticated tools. }\end{array}$ & $\begin{array}{l}\text { "... our reporting out of Salesforce is something that we're working } \\
\text { on. I wouldn't mind looking at some stuff that some of the big } \\
\text { companies use like Tableau or QlikView or something like that, but } \\
\text { we haven't quite got to that next stage yet." (Acorn, CEO) }\end{array}$ \\
\hline
\end{tabular}

\section{Table 5. Case study findings for 'Information' element of DIKAR}

IT developments focus on facilitating the processing of data into information, in particular automation of data processing and report generation, which in turn requires structuring of data collection. Older and more complex organisations have problems overcoming historically developed systems that cannot easily be connected to produce integrated information. Data analysis does not currently involve sophisticated IT tools, though there is some interest in developing such expertise.

\section{Knowledge}

Table 6 below summarizes the key findings for the knowledge element of DIKAR. The data shows how trust and expertise are essential elements of well-functioning IPM.

\begin{tabular}{|c|c|c|}
\hline \multicolumn{2}{|c|}{ Key case study findings } & Key quotes \\
\hline \multirow{3}{*}{$\frac{\mathbb{0}}{\frac{5}{2}}$} & $\begin{array}{l}\text { Report writers and users rely on each } \\
\text { other's knowledge: to provide } \\
\text { contextualisation in and with reports; and } \\
\text { to fully understand the information } \\
\text { provided. }\end{array}$ & $\begin{array}{l}\text { "...they have to be able to rely on the projections into the future, and } \\
\text { the importance of understanding the context they're looking at those } \\
\text { figures in." (Bramble, CEO). } \\
\text { "...familiar with the day-to-day work that we do" (Acorn, } \\
\text { business/executive support) }\end{array}$ \\
\hline & $\begin{array}{l}\text { Mutual trust is a key factor; this is based on } \\
\text { providing good information, as well as } \\
\text { through relationships and communication. }\end{array}$ & $\begin{array}{l}\text { "irrespective of what you put in the report, they're still wanting the face- } \\
\text { to-face highlight of something, they want to know what's happening } \\
\text { [...]. They want to know ... if I'm enthused and happy, that's it." (Vine, } \\
\text { operations). }\end{array}$ \\
\hline & $\begin{array}{l}\text { The nature and operating model of the } \\
\text { charity impact on specific knowledge } \\
\text { challenges, including trust, for example } \\
\text { balancing artistic flair/social impact with } \\
\text { business acumen/commercial elements. }\end{array}$ & $\begin{array}{l}\text { "...bits of my decisions they can't understand because they're not in the } \\
\text { business, because they have to have trust in me on that" (Plane, CEO) }\end{array}$ \\
\hline
\end{tabular}




\begin{tabular}{|l|l|l|}
\hline & $\begin{array}{l}\text { No explicit knowledge management } \\
\text { systems were identified. IT here is about } \\
\text { sharing information (internally and }\end{array}$ & $\begin{array}{l}\text { "...everybody in the UK shares the server. It's a big obstacle that [...] } \\
\text { more than half of our staff are based overseas in Sri Lanka and in India } \\
\text { and in Kenya and in smaller, you know one or two people in offices in } \\
\text { externally), communication and } \\
\text { collaboration. The charity's operating } \\
\text { model has an impact, e.g. the need to } \\
\text { support a distributed organisation. Cloud } \\
\text { computing is of specific interest here. }\end{array}$ \\
& $\begin{array}{l}\text { "... all cloud-based systems basically offers us different ways of doing } \\
\text { things. [...] allow us to more coordinate the schools contents and the } \\
\text { work that schools are creating and collaborating using all of that, as } \\
\text { well as for our own internal monitoring systems." (Bramble, CEO). }\end{array}$ \\
\hline
\end{tabular}

Table 6. Case study findings on 'Knowledge' element of DIKAR

Several of the charities are investigating systems for improving the sharing and communication of information, but do not consider these knowledge systems. Such systems are particularly important - and challenging - in more distributed organisations. They align with the need for more integrated and streamlined data collection and processing. When taking a strategic approach to IT development, charities can thus benefit from considering data, information and knowledge in conjunction, rather than treating them separately.

\section{Action and Results}

The final DIKAR table (Table 7) shows Action and Results together, as they are closely related and neither shows a strong direct IT element.

\begin{tabular}{|c|c|}
\hline \multicolumn{2}{|r|}{ Action } \\
\hline Key case study findings & Key quotes \\
\hline $\begin{array}{l}\text { Information and knowledge directly support } \\
\text { organisational action related to PM at various } \\
\text { levels, including providing feedback, } \\
\text { interventions, and adjusting of forecasts and } \\
\text { plans. }\end{array}$ & $\begin{array}{l}\text { "...so some of that information, say the programme information, most } \\
\text { of it feeds back down again to inform us how we should do our work } \\
\text { maybe differently and where the gaps are and whatever..." (Vine, } \\
\text { operations). } \\
\text { "We know when to ask the executive to kind of go back and reforecast } \\
\text { and adjust their plan because it's not going to pan out if we continue } \\
\text { just on the railway lines we set at the beginning of the year." (Plane, } \\
\text { trustee). }\end{array}$ \\
\hline $\begin{array}{l}\text { The operational model has a major impact, } \\
\text { particularly where action is indirect and the } \\
\text { charity's management decisions have less direct } \\
\text { bearing on its impact. }\end{array}$ & $\begin{array}{l}\text { "We don't do the doing. The networks do the doing." (Vine, } \\
\text { operations). }\end{array}$ \\
\hline $\begin{array}{l}\text { An integrated perspective is important, because } \\
\text { different activities may depend on one another. }\end{array}$ & $\begin{array}{l}\text { "... the work that we do in the UK schools is dependent on us doing } \\
\text { work in New York schools, because they want to collaborate with } \\
\text { those schools. So you might say well that work in New York isn't cost- } \\
\text { effective, delete it - you might save a few thousand pounds, but you'd } \\
\text { probably lose } £ 50,000 \text { worth of income in the UK from doing that. [...]" } \\
\text { (Bramble, CEO). }\end{array}$ \\
\hline $\begin{array}{l}\text { Reporting can directly be used as a fundraising } \\
\text { tool. }\end{array}$ & $\begin{array}{l}\text { "...use our annual report more as a fundraising and communications } \\
\text { tool, but that's more us telling the world about us." (Vine, CEO). }\end{array}$ \\
\hline \multicolumn{2}{|r|}{ Result } \\
\hline $\begin{array}{l}\text { Impact is the ultimate result, achieved through a } \\
\text { variety of direct and indirect actions. Impact is } \\
\text { meaningful to all stakeholders, and can be hard } \\
\text { to measure, particularly where operating models } \\
\text { are more complex, but also because both } \\
\text { actions and impacts are often indirect. }\end{array}$ & $\begin{array}{l}\text { "...we track whether somebody's a primary, secondary or tertiary } \\
\text { beneficiary. So primary is somebody who's like directly benefited [...]; a } \\
\text { secondary is someone we trained, [...] so much of what we do is about } \\
\text { training people [...]. And then a tertiary is like an awareness raising } \\
\text { beneficiary [...]." (Willow, project development). }\end{array}$ \\
\hline
\end{tabular}


Demonstrating impact is bound up with compliance and accountability, as the public benefit needs to be demonstrated to justify the organisation's existence and its use of funding. "...they're effectively giving you money and they want to make sure you're spending it properly and the programmes you're running are actually what you said you're going to do and what they agreed to." (Willow, finance).

"...the annual accounts are much more about compliance and making sure that we have satisfied the public benefit needs" (Vine, CEO).

Table 7. Case study findings on 'Action' and 'Result' elements of DIKAR (no IT elements)

Information and knowledge within IPM contribute to making decisions on actions and plans. They also help the charities demonstrate impact and responsible use of funds. This supports their compliance and accountability, as well as their fundraising and income generating activities. Where charities work through networks, actions are indirect and feedback loops are complex and lengthy. Charities in the study have demonstrated a need for an integrated perspective as activities influence each other and relevant actions for achieving impact can extend beyond the direct zone of influence of the charity decision makers. Each of these make both measuring and attributing impact difficult, posing challenges to what data to collect and what information to produce.

\section{DIKAR model for charity IPM in practice}

Based on the case study findings, in particular the strong links between the DIKAR elements, the focus on understanding how actions drive impacts and the involvement of both internal and external actors, IPM in charities can be graphically presented using DIKAR as a cyclical feedback system (Figure 2).

Figure 2 Integrated Performance Management



The graphic shows how management decisions (Knowledge, far-left box) lead to charitable work being undertaken (Actions), which, together with external factors (e.g. network partners, society), lead to impacts (Results). Data is collected about actions, results and external factors. Targeted 
performance reporting (Information) is then done based on the integrated pool of data; this informs both external stakeholders and PM decisions, entering a new cycle.

\section{Conclusions}

This exploratory study shows that the case study SMCs are keen to provide integrated performance reporting and are strongly aware of the importance of IT as an enabler for IPM. It was found that the key to successful IPM in these charities is based on collecting data that enables impact measurement as well as insights into processes, combined with decision-makers' understanding of how actions, directly or indirectly, lead to impacts. The key contribution of this paper to literature lies in the empirical investigation of charity use of IT and how it can contribute to IPM, as well as how they view the drivers and barriers. IPM use in SMCs includes a) integrated collection and management of data on impact and processes; b) integrated performance reporting, addressing diverse stakeholder information needs from the same pool of data; and c) integrated use of organisational and networkwide knowledge on how impacts are achieved in order to decide on actions. Key challenges are establishing relevant performance measures and, subsequently, collecting the necessary data, particularly when, as is common, impacts are achieved (in part) indirectly through working with partners and in networks. Furthermore, deciding appropriate action based on the information derived from data requires specific expertise and experience for decision makers to understand how actions may lead to impacts.

While IT does not directly make impact measurement less fraught, as there are inherent difficulties in creating relevant measures and attribution of impacts to particular actions, it can provide substantial support for IPM. The IT barriers/drivers section shows there are strong drivers and fewer barriers to IT use for IPM. The case study organisations generally have a positive attitude towards IT, and receive support from umbrella bodies and IT organisations. Some make innovative use of IT to achieve their charitable aims and there is increasingly good use of low-cost cloud solutions. A key insight is that charities would benefit from less emphasis on ad-hoc solutions for specific problems, but rather need to integrate IT into strategic decision-making and organisational activities. An infrastructural approach to IT includes joined-up planning of IT for data collection, data collating and processing (information), and communication (knowledge). Rather than pursuing separate IT solutions once decisions about data, information and knowledge have been made, IT infrastructure requirements need to be central to such decisions. 
The necessary long-term strategic attitude to IT infrastructure needs enhanced trustee involvement in strategic IT management in individual charities and a more strategic umbrella approach for the wider charity sector. Further research is needed into how this might be achieved.

\section{Acknowledgement}

The researchers are grateful for funding received from ICAS and The Scottish Accountancy Trust for Education and Research (SATER), now known as the ICAS Foundation.

\section{References}

Anheier (2000), Managing non-profit organisations: Towards a new approach. Civil Society Working Paper, 1.

Benbasat, I., Dexter, A.S., Drury, D.H. and Goldstein, R.C. (1984), A critique of the stage hypothesis: theory and empirical evidence. Communications of the ACM, 27, 5, p. 476-485.

Bushouse, B.K. and Sowa, J.E. (2012), Producing Knowledge For Practice: Assessing NVSQ 2000-2010. Nonprofit and Voluntary Sector Quarterly, June 2012, 41, p. 497-513.

Caldeira, M.M. and Ward, J.M. (2003), Using resource-based theory to interpret the successful adoption and use of information systems and technology in manufacturing small and mediumsized enterprises. European Journal of Information Systems, 12, p. 127-141.

Checkland, P. and Holwell, S. (1998). Information, Systems and Information Systems. Chichester: John Wiley \& Sons Ltd.

Clerkin, R.M. and K.A. Grønbjerg (2007), Infrastructure and Activities: Relating IT to the Work of Nonprofit Organizations. In: Cortés, M. and Rafter, K.M. (eds) (2007), Nonprofits \& Technology: Emerging Research for Usable Knowledge (Lyceum), p. 3-20.

Connolly, C. \& Hyndman, N. (2013), Charity accountability in the UK: through the eyes of the donor. Qualitative research in Accounting \& Management, 10, 3/4, p. 259-278.

Cordery C., Sinclair R., (2013), Measuring performance in the third sector. Qualitative Research in Accounting \& Management, 10, 3/4, p.196-212.

Cortés, M. and Rafter, K.M. (2007), Introduction. In: Cortés, M. and Rafter, K.M. (eds) (2007), Nonprofits \& Technology: Emerging Research for Usable Knowledge (Lyceum), p. ix-xxi.

Dacombe, R. (2011), Can we argue against it? Performance management and state funding of voluntary organizations in the UK. Public Money \& Management, 31, 3, p.159-166.

Davenport, T.H., DeLong, D. and Beers, M. (1998), Successful knowledge management projects. Sloan Management Review, Winter, 1998, p. 43-57.

Dresner, H. (2008), The Performance Management Revolution; Business Results through Insight and Action (John Wiley \& Sons).

Emrich, E. and Pierdzioch, C. (2016), The Internet and the Commitment of Volunteers: Empirical Evidence for the Red Cross. Nonprofit and Voluntary Sector Quarterly, first published on January 12, 2016, doi:10.1177/0899764015624980.

Frolick, M. N. and Ariyachandra, T.R. (2006), Business performance management: One truth. Information Systems Management, 23, 1, p. 41-48.

Gallegos, D., Russell-Bennett, R. and Previte, J. (2011), An Innovative Approach to Reducing Risks Associated With Infant Feeding: The Use of Techology. Journal of Nonprofit \& Public Sector Marketing, 23, p. 237-347. 
Hackler, D. and G. D. Saxton (2007), The Strategic Use of Information Technology by Nonprofit Organizations: Increasing Capacity and Untapped Potential. Public Administration Review, 67, 3, p. 474-487.

Kobelsky, K., Larosiliere, G. and Plummer, E. (2014), The impact of information technology on performance in the not-for-profit sector. International Journal of Accounting Information Systems, 15, p. 47-65.

Luke, B., Barraket, J. and Eversole, R. (2013), Measurement as legitimacy versus legitimacy of measures - performance evaluation of social enterprise. Qualitative Research in Accounting \& Management, 10, 3/4, p. 234-258.

Manzo, P. and Pitkin, B. (2007), Barriers to Information Technology Usage in the Nonprofit Sector. In: Cortés, M. and Rafter, K.M. (eds) (2007), Nonprofits \& Technology: Emerging Research for Usable Knowledge (Lyceum), p. 49-51.

Marr, B. (2008), Strategic Performance Management in Government and Public Sector Organisations. Research Paper, API, sponsored by CIPFA and Actuate.

Melchert, F. and Winter, R. (2004), The enabling role of information technology for business performance management. IFIP International Conference on Decision Support Systems, p. 535546.

Morgan, G.G. (2013), Purposes, activities and beneficiaries: assessing the use of accounting narratives as indicators of third sector performance. Qualitative Research in Accounting \& Management, 10, 3/4, p. 295-315.

Moxham C, (2014), Understanding third sector performance measurement system design: a literature review. International Journal of Productivity and Performance Management, 63, $6 \mathrm{p}$. 704-726.

Moxham, C. (2013), Measuring up: examining the potential for voluntary sector performance measurement to improve public service delivery. Public Money \& Management, 33, 3, p. 193-200.

Neely, A., B. Yaghi and N. Youell (2008), Enterprise Performance Management: The Global State of the Art. Oracle and Cranfield School of Management.

Nicholls, A. (2009). 'We do good things, don't we?'; 'Blended Value Accounting' in social entrepreneurship. Accounting, organizations and society, 34, 6, p. 755-769.

Saxton G.D. and Guo, C. (2011), Accountability Online: Understanding the Web-Based Accountability Practices of Nonprofit Organizations. Nonprofit and Voluntary Sector Quarterly, April 2011, 40, p. 270-295.

Sloan, A. (2013), Is the way we view the voluntary sector counter-productive to charities? The Guardian, Thursday 11 April 201306.30 BST (accessed online on 29-06-2015).

Svensson, P.G., Mahoney, T.Q. and Hambrick, M.E. (2015), Twitter as a Communication Tool for Nonprofits: A Study of Sport-for-Development Organizations. Nonprofit and Voluntary Sector Quarterly, December 2015, 44, p. 1086-1106.

Walsham, G. (1995), Interpretive case studies in IS research: nature and method. European Journal of Information Systems, 4, p. 74-81.

Ward, J. and J. Peppard (2016), The Strategic Management of Information Systems (John Wiley \& Sons Ltd).

Wolpert, J. and Seley, J.E. (2007), The Use of Computer and Office Technology among New York City's Nonprofit Organization. In: Cortés, M. and Rafter, K.M. (eds) (2007), Nonprofits \& Technology: Emerging Research for Usable Knowledge (Lyceum), p. 21-32.

Yin, R.K. (2014), Case Study Research. Design and Methods (Sage).

Zhang, W., Gutierrez, O. and Mathieson, K. (2010), Information Systems Research in the Nonprofit Context: Challenges and Opportunities. Communications of the Association for Information Systems, 27, p. 1-12.

Zorn, T.E., A.J. Flanagin and M.D. Shoham (2011). Institutional and Noninstitutional Influences on Information and Communication Technology Adoption and Use Among Nonprofit Organizations. Human Communication Research, 37, 1, p. 1-33. 